\title{
PENGGUNAAN BAHASA INDONESIA PADA SURAT DINAS DI KANTOR PERBEKEL DESA PENGLUMBARAN KABUPATEN BANGLI SERTA IMPLIKASINYA TERHADAP PEMBELAJARAN MENULIS SURAT DI SEKOLAH
}

\author{
I Kd. Darmadi Adiyasa1, I W. Artika², I W. Rasna ${ }^{3}$ \\ Jurusan Pendidikan Bahasa dan Sastra Indonesia, Fakultas Bahasa dan Seni \\ Universitas Pendidikan Ganesha \\ Singaraja, Indonesia \\ e-mail: \{darmadiadiyasa565@gmail.com, wayan.artika@undiksha.ac.id, \\ wayanrasna@ymail.com\}
}

\begin{abstract}
ABSTRAK
Penelitian ini bertujuan untuk mendeskripsikan (1) kesalahan penggunaaan ejaan pada surat dinas yang disusun pegawai kantor Perbekel Desa Penglumbaran. (2) kesalahan penggunaan pilihan kata pada surat dinas yang disusun pegawai kantor Perbekel Desa Penglumbaran. (3) implikasi penggunaan bahasa Indonesia terhadap pembelajaran menulis surat di sekolah. Penelitian ini menggunakan rancangan deskriptif kualitatif. Subjek penelitian ini adalah surat dinas yang dikeluarkan pegawai kantor Perbekel Desa Penglumbaran. Objek penelitian ini adalah penggunaan bahasa Indonesia pada surat dinas yang meliputi penggunaan ejaan, pilihan kata dan penggunaan bahasa Indonesia pada pembelajaran menulis di sekolah. Data yang dikumpulkan berupa surat dinas dengan menggunakan metode dokumentasi. Hasil penelitian ini ialah (1) kesalahan penggunaan ejaan dalam surat dinas memiliki kesalahan sebanyak 95 kesalahan pemakaian huruf, 5 kesalahan penulisan kata, dan 379 kesalahan penggunaan tanda baca. (2) kesalahan penggunaan pilihan kata dalam surat dinas memiliki kesalahan (a) kesalahan kelangsungan pilihan kata/diksi berjumlah 33 kesalahan, (b) kesalahan penggunaan kata tidak baku 20 kata. (3) implikasi penggunaan bahasa Indonesia pada penelitian ini, yaitu implikasi teoritis yang memberikan penegasan teori yang berkaitan dengan penggunaan ejaan dan diksi. Kemudian implikasi praktis, dapat memberikan pengetahuan bagi pembaca mengenai penggunaan ejaan dan pemilihan kata/diksi. Simpulan penelitian ini adalah (1) kesalahan terbanyak ditemukan pada penggunaan ejaan 479 kesalahan. (2) kesalahan pemilihan kata sebanyak 53 kesalahan. (3) implikasi penelitian ini dibedakan menjadi dua yaitu implikasi teoretis dan implikasi praktis. Saran penelitian ini ialah, pegawai kantor Perbekel Desa Penglumbaran harus memiliki pedoman penggunaan EYD yang benar sebagai pedoman. Selain itu, untuk balai bahasa hendaknya melakukan penyuluhan bahasa ke desa-desa.
\end{abstract}

Kata kunci: kantor, penggunaan bahasa Indonesia, surat dinas

\section{ABSTRACT}

This study aimed for describing 1) the use of spelling in formal letter organized by office of Perbekel Desa Penglumbaran. 2) the use of word choice in formal letter organized by office of Perbekel Desa Penglumbaran. 3) the implication of the use of Indonesian language to the lesson of letter's writing in the school. This study used descriptive qualitative design. The subject of this study were the formal letter organized by the officer of Kantor Perbekel Desa Penglumbaran. The object of this study was the use of Indonesian language including the use of spelling, word choice and the use of Indonesian language in lesson writing in the school. The data was collected by using documentation. The result showed that: 1) the use of spelling in formal letter had error as many as 95 errors in terms of alphabet's use, 5 errors in 
terms of word choice, and 379 errors in terms of symbol's use. 2) the use of word choice in formal letter had errors such as: a) the choice of word directly/diction as many as 33 errors, b) the use of 20 nonformal words, 3) the implication of the use of Indonesian language in this study were: theoretical implication which provided the theory based on spelling and word choice. Then, practical implication which provided knowledge to the reader related to the use of spelling and word choice/diction. The conclusions of this study were: 1) the most error occurred in spelling which is 479 errors. 2) the errors of word choice occurred were 53 errors, 3) the implication of this study was divided into 2 such as theoretical and practical implication. This study suggested that, the officer of perbekel desa Penglumbaran must have the guideline of correct spelling. Besides that, balai bahasa must give socialization to the villages.

Keywords: office, the use of Indonesian language, formal letter

\section{PENDAHULUAN}

Bahasa memiliki peranan yang sangat penting dalam kehidupan manusia. Halliday (dalam Rahardi, 2008:6) berpendapat bahwa bagi umat manusia, bahasa menjadi piranti utama dalam berkomunikasi dan berinteraksi dengan sesamanya. Segala sesuatu yang dirasakan, dialami, dihayati, dan dipikirkan oleh seseorang hanya akan diketahui orang lain jika telah diungkapkan dengan bahasa. Melalui bahasa, manusia berkomunikasi untuk berbagai keperluan dalam kehidupannya, baik secara lisan maupun tulis dan secara langsung maupun tidak langsung serta secara resmi maupun tidak resmi.

Bahasa Indonesia adalah bahasa yang sangat penting dikawasan Republik Indonesia. Pentingnya peranan bahasa itu antara lain bersumber pada ikhar ketiga Sumpah Pemuda 1928 yang berbunyi: "kami putra dan putri Indonesia menjungjung bahasa persatuan, bahasa Indonesia" dan pada undang-undang yang didalamnya tercantum pasal khusus yang menyatakan bahwa "bahasa negara ialah bahasa Indonesia". Namun, disamping itu masih ada beberapa alasan lain mengapa bahasa Indonesia menduduki tempat yang terkemuka diantara beratus-ratus bahasa Nusantara yang masing-masing amat penting bagi penuturnya sebagai bahasa ibu.

Bahasa Indonesia memiliki dua fungsi yaitu secara lisan dan tulis. Menurut Suwarna (2012:8) kehadiran bahasa lisan teramat diperhatikan, sementara dalam bahasa tulis tidak. Subjek berwujud menjelaskan langsung tidaknya komunikasi yang dilakukan. Dalam bahasa tulis, alat bantu seperti pensil, pena, atau pengetikan hasil komputer menegaskan bahwa komunikasi yang terjadi adalah tidak langsung. Setiap pemakaian media atau alat bantu menjelaskan hakikat komunikasi tidak langsung.

Saat ini bahasa Indonesia sudah memiliki peraturan cukup ketat dan pembendaharaan kata yang cukup banyak. Berarti bahasa Indonesia cukup memadai atau mampu sebagai wadah dan media penyampai informasi dengan jelas tanpa perlu mencampuradukan bahasa asing. Kenyataan ini mendorong masyarakat agar lebih mengedepankan penggunaan bahasa Indonesia daripada bahasa asing. Sebagai masyarakat Indonesia sudah selayaknya dan wajib menggunakan bahasa Indonesia dengan baik dan benar. Tujuan utama penggunaan bahasa Indonesia ini sebenarnya untuk menjaga identitas bangsa dan untuk mereduksi masuknya pengaruh bahasa asing ke dalam ranah penggunaan bahasa Indonesia.

Bahasa Indonesia merupakan bahasa nasional dan bahasa pemersatu bangsa ini. Pembelajaran bahasa Indonesia sudah dimulai sejak dini. Dilingkungan sekolah para siswanya sudah diharuskan berkomunikasi dengan bahasa Indonesia dengan baik. Meskipun demikian penduduk di Desa Penglumbaran lebih sering berkomunikasi dengan bahasa masing-masing dusun. Sebagian besar penduduk Desa 
Penglumbaran khusnya dari umur 50 tahun keatas lebih banyak tidak bisa berbahasa Indonesia yang baik. Penduduk disetiap dusun juga terkesan enggan berbahasa Indonesia karena mereka takut bahasa Bali akan terlupakan seiring berkembangnya bahasa Indonesia.

Pemakaian bahasa Indonesia di Desa Penglumbaran hanya digunakan pada saat acara formal saja, seperti rapat umum desa, penyuluhan, kunjungan resmi, dan administrasi perkantoran. Tetapi ada kurang lebih 7\% keluarga di Desa Penglumbaran yang sehari-harinya menggunakan bahasa Indonesia, biasanya masyarakat yang pindah dari kota atau yang sejak kecil dibiasakan menggunakan bahasa Indonesia (Profil Desa Penglumbaran, 2016). Karena masyarakat desa lebih sering menggunakan bahasa Bali, saat berbahasa Indonesia mengalami kesulitan bahkan saat berbicara tidak jarang memakai kata yang salah, atau diselingi dengan bahasa Bali yang bersangkutan. Salah satu warga yang menggunakan bahasa Indonesia setiap harinya ialah, keluarga dari bapak I Wayan Kusuma Yasa.

Pada dasarnya, pemakaian bahasa Indonesia di Desa Penglumbaran masih sangat kurang. Meskipun keadaan masyarakatnya cukup modern, masyarakat di Desa Penglumbaran masih menjalankan aturan adat dengan sistem gotong royongnya sehingga sebagian besar masyarakatnya cendrung menggunakan bahasa Bali sebagai alat untuk berkomunikasi disetiap kegiatan adat. Hal inilah yang menyebabkan kurangnya penggunaan bahasa Indonesia di Desa Penglumbaran.

Sebagian besar wilayah Desa Penglumbaran berada di jalur utama provinsi dan kabupaten. Didukung dengan pemandangan alam yang masih hijau, sumber daya alam yang memadai, dan beberapa kerajinan tangan seperti ukiran berbahan akar bambu dan lain-lain yang cukup dilirik pasar wisata lokal maupun mancanegara. Pariwisata menjadi mata pencaharian utama di Desa
Penglumbaran sehingga, tidak heran banyak masyarakat yang tertarik untuk mempelajari bahasa asing.

Berkembang pesatnya pariwisata di Desa Penglumbaran membawa dampat baik bagi penduduknya. Hasil yang dijanjikan dari pariwisata juga sangat menggiurkan sehingga, banyak masyarakat termotivasi untuk lebih menekuni dunia pariwisata. Maka tidak heran jika hampir $70 \%$ penduduk usia dini lebih memilih melanjutkan pendidikan ke sekolah kejuruan atau kampus pariwisata (Profil Desa Penglumbaran, 2016). Hal lain yang dilakukan adalah dengan mengikuti kursus-kursus bahasa asing yang kini kian menjamur di kota-kota lain.

Masyarakat Desa Penglumbaran khususnya anak-anak lebih senang mempelajari bahasa asing. Selain terletak di lingkungan pariwisata, ada beberapa penyebab lain yang menyebabkan kurangnya penggunaan bahasa Indonesia yaitu, minimnya bacaan, tidak mau taunya masyarakat akan bahasa nasional mereka, masyarakat lebih cenderung mempelajari bahasa asing (Inggris, Rusia, Jepang dII). Sebagian besar siswa di Desa Penglumbaran lebih banyak memilih jurusan yang berkaitan dengan kepariwisataan. Mulai dari anak-anak dari jenjang SMA/SMK - kuliah lebih banyak yang mengambil jurusan yang berhubungan dengan kepariwisataan misalnya guiding berjumlah $20 \%, F \& B$ Service berjumlah 30\%, Bar berjumlah $25 \%$, Front Office berjumlah $10 \%$ Tata Boga berjumlah 5\%, lain-lain 5\% (Profil Desa Penglumbaran, 2016). Bahkan tidak hanya itu anak-anak SD dari kelas 5 ke atas sampai dengan jenjang SMP sudah mulai mengikuti les bahasa Inggris dan bahasa Jepang karena, hal tersebut dianggap lebih bermanfaat dan lebih menguntungkan daripada bahasa Indonesia. Sangat jarang dan hampir tidak ada pelajar yang berminat lebih mendalami dan mengembangkan pelajaran bahasa Indonesia. Kebanyakan orang berpikiran bahasa Indonesia adalah bahasa wajib yang sudah ditanamkan sejak kecil dan tidak perlu untuk dipelajari 
kembali. Padahal bahasa Indonesia adalah salah satu bahasa paling sulit di dunia. Ditengah itulah bahasa Indonesia masih digunakan di Desa Penglumbaran untuk pembuatan administrasi perkantoran.

Bahasa Indonesia digunakan disemua lembaga instansi pemerintahan, hal ini dikarenakan bahasa Indonesia merupakan bahasa kesatuan republik Indonesia. Di Desa Penglumbaran sendiri memiliki beberapa lembaga instansi pemerintahan diantaranya ialah, 1). SD Negeri 1 Penglumbaran, 2). SD Negeri 2 Penglumbaran, 3). kantor Perbekel Desa Penglumbaran. Pemakaian bahasa Indonesia sudah dianjurkan disetiap instansi pemerintahan seperti sekolah, kantor, rumah sakit, dan instansi-instansi pemerintah lainnya. Bahkan bahasa Indonesia sudah digunakan untuk berkomunikasi di sekolah dasar. Meskipun terkadang untuk anak-anak SD khususnya kelas $1-3$, bahasa Indonesia masih menjadi bahasa baru yang masih sulit untuk dimengerti, hal yang sama juga berlaku di kantor-kantor pemerintahan lainnya. Bahasa Indonesia dijadikan sebagai alat komunikasi namun, terkadang pegawai kantor Perbekel Desa Penglumbaran masih menggunakan bahasa Bali, dan hanya menggunakan bahasa Indonesia pada saat melakukan pembuatan administrasi perkantoran.

Seperti yang tertera pada Undangundang republik Indonesia BAB III pasal 29 ayat I yang menyebutkan bahwa "bahasa Indonesia wajib digunakan sebagai bahasa pengantar dalam pendidikan nasional" dan pasal 33 ayat I yang menyebutkan bahwa "bahasa Indonesia wajib digunakan dalam komunikasi resmi di lingkungan kerja pemerintahan dan swasta (Undangundang republik Indonesia, 2009).

Meskipun penggunaan bahasa Indonesia masih belum sempurna namun, pembuatan administrasi di Desa Penglumbaran harus tetap dibuat sebagaimana mestinya. Seperti yang tertera dalam Undang-undang republik Indonesia 1995 pasal 30 disebutkan bahwa "bahasa Indonesia wajib digunakan dalam pelayanan administrasi publik di instansi pemerintahan" (Undang-undang republik Indonesia, 2009). Administrasi perkantoran tersebut antara lain pembuatan profil desa, slip gaji, laporan tahunan, laporan kerja, surat dinas, dll.

Pembuatan surat dinas ini merupakan sarana komunikasi yang digunakan untuk menginformasikan kepada pihak yang akan dituju. Terkadang pegawai administrasi di kantor Perbekel Desa Penglumbaran terkesan hanya sekadar membuat para pembaca mengerti dengan apa yang hendak disampaikan dalam surat tersebut tanpa mementingkan aturan dan tata cara menulis surat yang baik dan benar. Sebagian masyarakat malah tidak tahu kalau bahasa Indonesia memiliki banyak aturan penulisan seperti, penggunaan ejaan, penggunaan tanda baca, pemilihan kata dan lain sebagainya. Hal inilah yang menyebabkan kurang telitinya perangkat desa dalam proses pembuatan surat. Karena masyarakat tidak akan tahu benar atau salahnya surat yang dikeluarkan oleh perangkat desa.

Oleh karena itu, sebelum menulis surat penulis harus mempertimbangkan dengan baik susunan kalimat, pilihan kata (diksi), dan ejaan serta pemakaian tanda baca yang dapat memperjelas maksud surat. Selain itu, penulis surat juga harus menghindari pemakaian kata atau bahasa yang kurang tepat dan memperhatikan pedoman penulisan surat. Berdasarkan penjelasan di atas, surat dinas yang dikeluarkan kantor Perbekel Desa Penglumbaran ideal menjadi subjek penelitian.

\section{METODE PENELITIAN}

Rancangan penelitian yang digunakan dalam penelitian ini adalah rancangan deskriftif kualitatif. Penelitian ini diharapkan mampu mendeskripsikan kesalahan penggunaan bahasa Indonesia pada surat dinas yang dikeluarkan kantor Perbekel Desa Penglumbaran. Subjek penelitian ini adalah surat dinas yang dikeluarkan kantor Perbekel Desa Penglumbaran, sedangkan objek 
penelitian ini adalah penggunaan bahasa pada surat dinas yang dikeluarkan kantor Perbekel Desa Penglumbaran yang meliputi, penggunaan ejaan, diksi dan penggunaan bahasa Indonesia pada pembelajaran menulis di sekolah.

Metode pengumpulan data dalam penelitian ini ialah menggunakan metode dokumentasi. Dalam penelitian ini, dokumen yang akan didokumentasikan dan data yang akan dianalisis ialah surat dinas yang dikeluarkan oleh kantor Perbekel Desa Penglumbaran dengan mencari langsung sumber di kantor Perbekel Desa Penglumbaran. Penggunaan metode dokumentasi ini digunakan untuk menjawab rumusan masalah pertama, kedua dan ketiga.

Selanjutnya, teknik analisis data yang digunakan dalam penelitian ini adalah teknik analisis deskriptif kualitatif yang menggunakan prosedur model analisis Miles dan Huberman (Sugiyono 2009:246) yang terdiri atas reduksi data (reduction data) yang dilakukan pemilihan hal-hal pokok, memfokuskan pada hal-hal penting, dan membuang yang tidak perlu.

Penyajian data (data display) yang dilakukan dengan mengolah dan menganalisis data untuk memperoleh jawaban yang tepat yang sesuai dengan rumusan masalah. Selain itu data yang didapat akan dihubungkan dengan teoriteori yang relevan untuk ditemukan kelayakannya. Dengan demikian, permasalahan yang diajukan dalam penelitian ini dapat terjawab.

Penarikan kesimpulan atau verifikasi (conclusion drawing) penyimpulan yang dilakukan harus dapat menjawab semua masalah yang diangkat dalam penelitian. Adapun simpulan penelitian ini meliputi (1) penggunaan ejaan pada surat dinas di kantor Perbekel Desa Penglumbaran, (2) penggunaan pilihan kata pada surat dinas di kantor Perbekel Desa Penglumbaran, (3). implikasi penggunaan bahasa Indonesia pada surat dinas terhadap pembelajaran menulis surat dinas di sekolah.

\section{HASIL DAN PEMBAHASAN}

Hasil penelitian meliputi (1) kesalahan penggunaan ejaan pada surat dinas (2) kesalahan pemilihan kata/diksi pada surat dinas. Berikut dipaparkan hasil temuan yang diperoleh dari analisis 20 surat dinas yang dikeluarkan kantor Perbekel Desa Penglumbaran.

Data mengenai penggunaan ejaan pada surat dinas yang dikeluarkan kantor Perbekel Desa Penglumbaran diperoleh menggunaakan metode dokumentasi. Data yang didokumentasikan ialah berupa 20 surat dinas yang dikeluarkan kantor Perbekel Desa Penglumbaran. Hasil yang diproleh dari penggunaan metode dokumentasi ialah (1) penggunaan ejaan pada surat dinas (2) pemilihan kata/diksi pada surat dinas (3) implikasi penelitian terhadap pembelajaran menulis surat di sekolah.

Pertama, penggunaan ejaan pada surat dinas yang dikeluarkan kantor Perbekel Desa Penglumbaran. Dari 20 surat dinas yang dianalisis terdapat kesalahan penggunan ejaan. Kesalahan penggunaan ejaan pada surat dinas yang dikeluarkan kantor Perbekel Desa Penglumbaran dilihat dari tiga jenis penggunaan ejaaan yaitu, (1) pemakaian huruf, (2) Penulisan kata, dan (3) pemakaian tanda baca. Adapun jumlah kesalahannya ialah, (a) pemakaian huruf 95 kesalahan. (b) penulisan kata 5 kesalahan. (c) penggunaan tanda baca 379 kesalahan. Adapun pemaparan kesalahaan penggunan ejaan sebagai berikut.

Pemakaian huruf pada surat dinas yang dikeluarkan kantor Perbekel Desa Penglumbran memiliki kesalahan pemakaian huruf. Kesalahan pemakaian huruf harus dihindari dalam penulisan. Pemakaian huruf terdiri dari pemakaian huruf kapital dan pemakaian huruf miring. Berdasarkan hasil analisis dari 20 surat dinas yang dikeluarkan kantor Perbekel Desa Penglumbaran, kesalahan pemakaian huruf ada pada setiap data yang ditemukan dari data nomor A. 1 sampai dengan data nomor A. 20. Kesalahan terbanyak terdapat pada penulisan huruf kapital dengan jumlah 
kesalahan 92 kesalahan. Sedangkan kesalahan penulisan huruf miring ditemukan sebanyak 3 kesalahan.

Selanjutnya, kesalahan penulisan kata. Pada dasarnya suatu kalimat tersusun dari beberapa kata yang berbeda yang membentuk suatu pengertian yang dapat dipahami. Penulisan kata dapat dibagi menjadi dua yaitu, (1) kata depan di, ke dan dari. (2) kata singkatan atau akronim. Berdasarkan analisis pada 20 surat dinas, ditemukan 5 kesalahan penulisan kata. Dari 5 kesalahan tersebut, kesalahan paling banyak ditemukan pada penulisan kata depan "di" yang berjumlah 4 kesalahan. Sedangkan kesalahan penulisan singkatan atau akronim hanya terdapat 1 kesalahan.

Kemudian, kesalahan penggunaan tanda baca. Dari 20 surat dinas yang dianalisis, kesalahan terbanyak ditemukan pada (1) kesalahan pemakaian tanda titik sebanyak 153 kesalahan. (2) kesalahan pemakaian tanda garis miring sebanyak 92 kesalahan. (3) kesalahan pemakaian tanda titik dua sebanyak 57 kesalahan. (4) kesalahan pemakaian tanda koma sebanyak 55 kesalahan. (5) kesalahan pemakaian tanda hubung sebanyak 18 kesalahan. (6) tidak ditemukannya kesalahan penggunaan tanda titik koma pada surat dinas yang dikeluarkan kantor Perbekel Desa Penglumbaran.

Menulis surat bukanlah hal yang asing disemua lembaga atau instansi pemerintahan baik negeri maupun swasta. Pembuatan surat dinas tidak terlepas dari penggunaan ejaan. Penggunaan ejaan dibagi menjadi tiga jenis yaitu (1) pemakaian huruf. (2) penulisan kata. (3) penggunaan tanda baca. Banyak orang menganggap penggunaan ejaan itu masalah yang tidak begitu penting. Namun, dampaknya sangat penting bagi eksistensi suatu bahasa.

Bahasa tulis sebagai salah satu bentuk wacana yang menggunakan bahasa sebagai mediumnya. Hal ini berkaitan dengan pernyataan Tarigan (2008:21) yang mengatakan menulis adalah menurunkan atau melukiskan lambang-lambang, yang menggambarkan suatu bahasa yang dipahami seseorang.

Surat dinas sebagai salah satu bentuk alat komunikasi pengganti dan menggunakan bahasa dalam bentuk tulis yang disajikan dengan jelas. Kejelasan isi dalam sebuah surat dinas, salah satunya perlu ditunjang penguasaan penggunaan ejaan yang baik agar, pihak pembaca/penerima surat dapat dengan jelas memahami isi dan maksud surat yang dibuat.

Tidak hanya penggunaan ejaan, pemilihan kata/diksi juga harus diperhatikan dalam bahasa tulis. Selain untuk memperjelas maksud yang ingin disampaikan, pemilihan kata yang kurang tepat sering sekali mengaburkan makna.

Kedua, pemilihan kata/diksi pada surat dinas yang dikeluarkan kantor Perbekel Desa Penglumbaran. Analisis pemilihan kata/diksi terhadap 20 surat dinas yang dikeluarkan kantor Perbekel Desa Penglumbaran berjumlah 53 kesalahan. Adapun pemaparan kesalahan pemilihan kata/diksi sebagai berikut.

Dalam penulisan surat, makna yang disampaikan harus memiliki makna yang jelas. Kosasih dan Finosa (dalam Ulyani, 2012) mengemukakan ciri-ciri bahasa dalam surat dinas ialah, bahasa yang jelas, bahasa baku, memiliki makna yang jelas, bahasa lugas dan kalimat singkat.

Dari 20 surat dinas yang dianalisis kesalahan terbanyak terdapat pada kelangsungan pemilihan kata sebanyak 33 kesalahan sedangkan, penggunaan kata tidak baku sebanyak 20 kata.

Pemilihan kata/diksi dipengaruhi oleh kemampuan pengguna bahasa yang terkait dengan kemampuan mengetahui, memahami, menguasai dan menggunakan sejumlah kosakata secara aktif yang dapat mengungkapkan gagasan secara tepat sehingga, mampu mengomunikasikannya secara efektif kepada pembaca.

Efektifitas komunikasi menuntut persyaratan yang harus dipenuhi oleh pengguna bahasa yaitu kemampuan memilih kata yang sesuai dengan tuntutan komunikasi. Indikator ketepatan kata/diksi 
menurut Widjono (dalam Santoso, 2014:19), antara lain: (1) mengomunikasikan gagasan berdasarkan pilihan kata yang tepat dan sesuai berdasarkan kaidah bahasa Indonesia. (2) menghasilkan komunikasi puncak (yang paling efektif) tanpa salah penafsiran atau makna. (3) menghasilkan respon pembaca atau pendengar sesuai dengan harapan penulis atau pembicara, dan (4) menghasilkan target komunikasi yang diharapkan.

Kesalahan penggunaan ejaan dan pemilihan kata/diksi harus dihindari dalam penulisan surat dinas. Upaya untuk mengoptimalkan penulisan surat dinas yang memenuhi syarat dan kaidah bahasa perlu dilakukan studi yang lebih mendalam tentang penggunaan ejaan pada surat dinas. Hal ini bertujuan tuntuk memperkecil tingkat kesalahan yang mungkin terjadi dalam penulisan surat.

Ketiga, implikasi penelitian terhadap pembelajaran menulis surat di sekolah. Dari hasil analisis 20 surat dinas yang dikeluarkan kantor Perbekel Desa Penglumbaran ditemukan dua implikasi yaitu, implikasi teoritis dan implikasi praktis. (1) implikasi teoritis, hasil penelitian ini telah memberikan penegasan kepada teori yang telah ada yang berkaitan dengan penggunaan ejaan dan diksi. Selain itu, hasil penelitian ini juga memperkaya pustaka atau referensi kajian menganai pengajaran bahasa, khususnya pembelajaran menulis surat. (2) implikasi yang berisifat praktis. Secara umum penelitian ini dapat memberikan pengetahuan bagi pembaca mengenai penggunaan ejaan dan pemilihan kata/diksi, kaidah kebahasaan pada surat dinas yang dapat dijadikan bahan ajar di sekolah. Secara khusus, penelitian ini dapat memperluas wawasan mahasiswa, guru atau dosen dalam melakukan kajian mengenai penggunaan ejaan dan diksi pada surat dinas.

Dengan adanya teori-teori kebahasaan yang digunakan sebagai acuan dalam penelitian ini, dapat menambah pengetahuan dan pemahaman pembaca tentang kebahasaan, khususnya dalam bidang ejaan dan penggunaan diksi yang benar pada surat dinas. Sebuah surat dinas yang baik harus memperhatikan penggunaan kaidah kebahasaan yang sesuai dengan kaidah bahasa Indonesia yang benar sedangkan, penggunaan ejaan dan pilihan kata yang digunakan pada surat dinas yang dikeluarkan kantor Perbekel Desa Penglumbaran ditemukan kaidah penggunaan ejaan dan pilihan kata yang tidak tepat. Dalam hal inilah penelitian ini berfungsi sebagai referensi dan contoh cara penulisan ejaan, pemilihan kata/diksi.

Penelitian ini juga dapat digunakan sebagai bukti bahwa, kaidah kebahasaan merupakan syarat mutlak yang harus dimiliki oleh penulis. Seorang penulis harus memiliki penguasaan kaidah kebahasaan yang baik karena akan memanfaatkannya sebagai media dalam menyampaikan gagasan. Gagasan tersebut harus diorganisasikan dengan sistematis dan logis sehingga menjadi tulisan yang dapat dipahami dan diterima oleh pembaca.

Berdasarkan hasil penelitian yang dipaparkan di atas, dari 20 surat dinas yang dianalisis kesalahan penggunaan ejaan terbanyak terdapat pada penggunaan tanda baca yang berjumlah 379 kesalahan. Hal ini dikarenakan oleh beberapa faktor yaitu, (1) kurangnya ketelitian dalam pembuatan surat dinas. (2) kurangnya pemahaman pegawai kantor Perbekel Desa Penglumbaran tentang penggunaan ejaan. (3) pegawai kantor Perbekel Desa Penglumbaran tidak mau mempelajari lebih dalam tentang penggunaan ejaan. (4) pegawai kantor Perbekel Desa Penglumbran berfikiran yang penting pembaca surat mengerti maksud yang ingin disampaikan. Pada penggunaan ejaan, pegawai kantor tidak mampu menggunakan atau memakai ejaan yang sesuai dengan kaidah bahasa Indonesia.

Misalnya, salah satu kesalahan terdapat pada data nomor C. 3. Pada data nomor C. 3, penulisan tanda koma dipakai pada akhir kalimat yang bukan pernyataan atau seruan. Sesuai kaidah 
penulisan bahasa Indonesia, setiap kalimat yang bukan pernyataan atau seruan di akhiri dengan tanda titik (Aleka dkk. 2010:299).

Selain kesalahan penggunaan ejaan, dalam penelitian ini juga akan membahas mengenai kesalahan pemilihan kata/diksi pada surat dinas yang dikeluarkan kantor Perbekel Desa Penglumbran.

Berdasarkan hasil penelitian yang dipaparkan di atas, dari 20 surat dinas yang dianalisis kesalahan pemilihan kata/diksi terbanyak terdapat pada kelangsungan pemilihan kata (logika berbahasa) dengan jumlah 33 kesalahan. Hal ini dikarenakan (1) kurangnya pemahaman kosa kata yang dikuasai. (2) kurangnya pemahaman pemakaian bahasa terhadap makna kata yang dipakai. (3) kurangnya pemahaman dalam proses pembentukan kata. Salah satu kesalahan pemilihan kata terdapat pada data nomor 18.

Analisis penggunaan ejaan dan diksi bukanlah hal baru dalam proses belajar mengajar, khususnya dalam belajar bahasa dan sastra Indonesia. Berdasarkan hasil dan pembahasan di atas, penelitian "Penggunaan Bahasa Indonesia pada Surat Dinas di kantor Perbekel Desa Penglumbaran Kabupaten Bangli serta Implikasinya Terhadap Pembelajaran Menulis Surat di Sekolah" ini memberikan implikasi terhadap hal-hal yang relevan. Implikasi penelitian ini dapat dibedakan menjadi dua, yaitu implikasi teoretis dan implikasi praktis.

Pertama, implikasi yang bersifat teoretis. Hasil penelitian ini telah memberikan penegasan kepada teori yang telah ada yang berkaitan dengan penggunaan ejaan dan diksi. Selain itu, hasil penelitian ini juga memperkaya pustaka atau referensi kajian menganai pengajaran bahasa, khususnya pembelajaran menulis surat. Umumnya, penggunan ejaan dan diksi diteliti menggunakan analisis korelasi, eksperimen atau penelitian tindakan kelas. Penelitian ini memberikan nuansa lain bahwa kajian terkait penggunaan ejaan dan diksi dapat dilakukan menggunakan pendekatan deskriptif kualitatif.

Kedua, implikasi yang berisifat praktis. Secara umum penelitian ini dapat memberikan pengetahuan bagi pembaca mengenai penggunaan ejaan dan pemilihan kata/diksi, kaidah kebahasaan pada surat dinas yang dapat dijadikan bahan ajar di sekolah. Secara khusus, penelitian ini dapat memperluas wawasan mahasiswa, guru atau dosen dalam melakukan kajian mengenai penggunaan ejaan dan diksi pada surat dinas.

Selain itu, penelitian ini juga dapat digunakan sebagai bukti bahwa, kaidah kebahasaan merupakan syarat mutlak yang harus dimiliki oleh penulis. seorang penulis harus memiliki penguasaan kaidah kebahasaan yang baik karena akan memanfaatkannya sebagai media dalam menyampaikan gagasan. Gagasan tersebut harus diorganisasikan dengan sistematis dan logis sehingga menjadi tulisan yang dapat dipahami dan diterima oleh pembaca.

Pemapaaran hasil penelitian yang meliputi kesalahan penggunaan ejaan dan diksi dapat membantu siswa dalam menghasilkan tulisan yang lebih berkualitas. Dengan menerapkan kaidah bahasa Indonesia yang tepat, secara tidak langsung siswa dapat menghasilkan tulisan yang baik. Selain itu, siswa juga bisa membedakan penggunaan bahasa yang benar dan tidak benar. Akhirnya, kesalahan-kesalahan tersebut tidak akan terulang lagi. Terkait dengan hal ini, peran guru sangat penting dalam upaya pembinaan bahasa Indonesia siswa. Guru dapat mengoreksi penggunaan kaidah bahasa siswa. Jika masih ditemukan kesalahan maka menjadi tugas guru untuk menunjukan kepada siswa agar kesalahan tersebut diperbaiki. Setelah siswa memperbaiki bentuk-bentuk kesalahan berbahasa dalan penulisannya, siswa akan lebih memperhatikan kaidah-kaidah kebahasaan yang digunakan saat menulis.

Dari hasil analisis 20 surat dinas yang dikeluarkan kantor Perbekel Desa Penglumbaran, kesalahan terbanyak 
terdapat pada penggunaan ejaan yang meliputi, kesalahan penggunaan tanda baca berjumlah 379 kesalahan. Kedua kesalahan pemakaian huruf berjumlah 95 kesalahan dan ketiga peulisan kata berjumlah 5 kesalahan.

Berdasarkan kesalahan tersebut, implikasi penelitian ini lebih ditekankan pada penggunaan ejaan pada saat pembelajaran menulis berlangsung agar hal yang sama tidak terulang kembali.

Hasil penelitian menunjukan bahwa salah satu faktor penyebab terjadinya kesalahan berbahasa adalah (1) pegawai kantor Perbekel Desa Penglumbaran kurangn memahami ejaan dalam bahasa Indonesia. (2) pegawai kantor Perbekel Desa Penglumbaran tidak memiliki pedoman penulisan surat.

Penulis berharap dengan meneliti 20 surat dinas yang dikeluarkan kantor Perbekel Desa Penglumbaran dapat menambah kemampuan dan antusias siswa untuk menulis, khusnya menulis surat dinas. Selain itu, manfaat lain yang diproleh adalah secara tidak langsung siswa telah melakukan analisis secara mendalam dan menambah ilmu bagi siswa yang jarang dilakukan pada pembelajaran menulis di sekolah.

\section{SIMPULAN DAN SARAN}

Ada beberapa simpulan yang dapat diambil berdasarkan hasil dan pembahasan penelitian yaitu, (1) Kesalahan penggunaan ejaan pada surat dinas yang dikeluarkan pegawai kantor Perbekel Desa Penglumbaran memiliki jumlah 479 kesalahan yang meliputi, (a) kesalahan pemakaian huruf berjumlah 95 kesalahan, (b) kesalahan penulisan kata berjumlah 5 kesalahan dan, (c) kesalahan penggunaan tanda baca berjumlah 379 kesalahan. (2) Kesalahan penggunaan pilihan kata pada surat dinas yang dikeluarkan pegawai kantor Perbekel Desa Penglumbaran memiliki jumlah 53 kesalahan yang meliputi (a) kesalahan kelangsungan pilihan kata berjumlaah 33 kesalahan dan (b) penggunaan kata tidak baku sebanyak 20 kata.
(3) Implikasi penggunaan bahasa Indonesia pada penelitian ini dibedakan menjadi dua yaitu, (a) implikasi teoritis, memberikan penegasan kepada teori yang telah ada yang berkaitan dengan penggunaan ejaan dan diksi. (b) implikasi praktis, memberikan pengetahuan bagi pembaca mengenai penggunaan ejaan dan pemilihan kata/diksi, kaidah kebahasaan pada surat dinas yang dapat dijadikan bahan ajar di sekolah. Selain itu, implikasi bahasa Indonesia pada penelitian ini ditekankan pada penggunaan tanda baca.

Berdasarkan pemaparan mengenai hasil penelitia dan simpulan, ada lima saran yang dapat disampaikan dalam penelitian ini.

Pertama, Guru mata pelajaran harus meningkatkan kreatifitas dalam kegiatan belajar mengajar khususnya pada materi penggunaan tanda baca dan penulisan huruf kapital dengan mengkombinasikan metode pembelajaran yang ada agar pembelajaran tersebut menjadi pembelajaran yang aktif, kreatif, inovatif dan menyenangkan. Kedua, pegawai di Kantor Perbekel Desa Penglumbaran harus memiliki buku pedoman penggunaan ejaan, pedoman pembuatan surat, dan Kamus Besar Bahasa Indonesia (KBBI) sebagai pedoman dalam penulisan surat dinas. Ketiga, Balai Bahasa hendaknya mengadakan sosialisasi dan penyuluhan bahasa khususnya ke desa-desa yang belum memahami penggunaan bahasa Indonesia yang baik dan benar. Keempat, siswa harus banyak-banyak membaca buku pedoman ejaan yang disempurnakan dan memahaminya. Siswa mengikuti arahan yang diberikan oleh guru dan lebih sering untuk melatih keterampilan menulisnya. Siswa dapat mengulang materi yang belum dipahami dan bertanya kepada teman atau guru. Serta siswa tidak mengulangi kesalahan yang telah dilakukan, yaitu kesalahan penggunaan tanda baca dan penulisan huruf kapital. Kelima, penelitian ini masih terbatas hanya mengkaji penggunaan ejaan dan pemilihan kata/diksi pada surat. Oleh 
karena itu, peneliti lain dapat melakukan kajian yang lebih luas seperti mengkaji dari segi struktur, dls. Dengan demikian, hasil penelitian ini dapat dijaadikan acuan ataupun perbandingan dalam melakukan penelitian sejenis.

\section{DAFTAR PUSTAKA}

Aleka, dkk. 2010. Bahasa Indonesia untuk Perguruan Tinggi. Jakarta: Karisma Putra Utama.

Profil Desa Penglumbaran, 2016. Penglumbaran: Tidak diterbitkan.

Sugiyono. 2009. Metode Penelitian Kualitatif Kuantitatif dan $R \& D$. Bandung: Alfabeta.

Suwarna, Dadan. 2012. Berbahasa Dengan Pemahaman dan Pendalaman. Tanggerang: Jelajah Nusa.
Tarigan, Henry Guntur. 2008. Menulis Sebagai Suatu Keterampilan Berbahasa. Bandung: Angkasa Bandung.

Ulyani, Mara. 2012. Buku Lengkap Aneka Surat Dinas. Yogyakarta: Flash Books.

Undang-Undang Republik Indonesia No. 24 Tahun 2009 BAB III tentang bahasa negara, 2009. Jakarta: Tidak diterbitkan.

Santoso. 2014. Penggunaan Diksi Dalam Karangan Narasi Siswa Kelas VIII MTs. Fathul' Ibaad Mekar Bakti Panongan, Tangerang. Tuga Akhir (tidak diterbitkan). Jurusan Pendidikan Bahasa dan Sastra Indonesia. Universitas Islam Negeri Syarif Hidayatulah Jakarta 